\title{
Elevated transforming growth factor $\beta$ and mitogen-activated protein kinase pathways mediate fibrotic traits of Dupuytren's disease fibroblasts
}

\author{
Carola Krause ${ }^{1,2}$, Peter Kloen ${ }^{3}$ and Peter ten Dijke
}

\begin{abstract}
Background: Dupuytren's disease is a fibroproliferative disorder of the palmar fascia. The treatment used to date has mostly been surgery, but there is a high recurrence rate. Transforming growth factor $\beta$ (TGF- $\beta$ ) has been implicated as a key stimulator of myofibroblast activity and fascial contraction in Dupuytren's disease.

Results: We studied Dupuytren's fibroblasts in tissues ex vivo and in cells cultured in vitro and found increased TGF- $\beta$ expression compared to control fibroblasts. This correlated not only with elevated expression and activation of downstream Smad effectors but also with overactive extracellular signal-regulated kinase 1/2 (ERK1/2)/mitogenactivated protein (MAP) kinase signalling. Treatment with the TGF- $\beta$ type I receptor kinase inhibitor SB-431542 and bone morphogenetic protein 6 (BMP6) led to inhibition of elevated Smad and ERK1/2/MAP kinase signalling as well as to inhibition of the increased contractility of Dupuytren's fibroblasts. BMP6 attenuated TGF- $\beta$ expression in Dupuytren's fibroblasts, but not in control fibroblasts. Platelet-derived growth factor (PDGF) expression was strongly promoted by TGF- $\beta$ in Dupuytren's fibroblasts and was curbed by SB-431542 or BMP6 treatment. High basal expression of phosphorylated ERK1/2 MAP kinase and fibroproliferative markers was attenuated in Dupuytren's fibroblasts by a selective PDGF receptor kinase inhibitor. Cotreatment of Dupuytren's fibroblasts with SB-431542 and the mitogen-activated protein kinase kinase 1 inhibitor PD98059 was sufficient to abrogate proliferation and contraction of Dupuytren's fibroblasts.

Conclusions: Both TGF- $\beta$ and ERK1/2 MAP kinase pathways cooperated in mediating the enhanced proliferation and high spontaneous contraction of Dupuytren's fibroblasts. Our data indicate that both signalling pathways are prime targets for the development of nonsurgical intervention strategies to treat Dupuytren's disease.
\end{abstract}

\section{Background}

Dupuytren's disease (DD) is a common fibroproliferative condition that only affects the hand. The characteristic feature is a progressive contracture of the palm and fingers. Patients commonly first display a nodule in the palm or on the volar (palmar) aspect of the fingers caused by a thickened layer of tissue (palmar fascia) between the skin and the tendons of the hand and fingers. The nodule is a key diagnostic feature and

\footnotetext{
* Correspondence: p.ten_dijke@lumc.nl

'Department of Molecular Cell Biology and Centre for Biomedical Genetics, Leiden University Medical Center, Einthovenweg 20, 2333 ZC Leiden, The Netherlands

Full list of author information is available at the end of the article
}

represents the early proliferative stage of the disease. The nodules contain mostly myofibroblasts $[1,2]$. As the disease progresses, the nodules may disappear and give way to the formation of cords. These cords represent characteristics of fibrosis within the involutional and residual stages of the disease and comprise mostly fibroblasts and extracellular matrix (ECM).

Treatment of DD consists largely of surgical excision of the contracted tissue. Because of high recurrence rates following surgery, investigations are underway to determine the underlying causes of DD to optimise treatment strategies $[1,2]$. The myofibroblast, a specialised fibroblast phenotype that expresses $\alpha$-smooth muscle actin ( $\alpha$-SMA), provides the cell with contractile 
activity [3-5]. To date, many growth factors have been implicated in Dupuytren's contracture; transforming growth factor $\beta$ (TGF- $\beta$ ) in particular has been proposed to play a prominent role [6].

TGF- $\beta$ is a member of a protein family that also includes activins, nodal and bone morphogenetic proteins (BMPs). TGF- $\beta$ protein family members signal through type I and type II serine/threonine kinase receptors [7]. Type I receptors are also called 'activin receptor-like kinases' (ALKs). ALK4, ALK5 and ALK7 are type I receptors of activin, TGF- $\beta$ and nodal protein kinases, respectively. SB-431542 is a selective inhibitor of ALK4, ALK5 and ALK7 kinase activity [8]. Signalling from activated type I receptors is mainly transduced into the cytoplasm through phosphorylation of receptor-regulated Smads (R-Smads). Activated ALK4, ALK5 and ALK7 induce phosphorylation of Smad2 and Smad3. BMPs mediate the activation of Smad1, Smad5 and Smad8. Activated R-Smads form heteromeric complexes with Smad4 that accumulate in the nucleus, where they regulate gene expression, including plasminogen activator inhibitor 1 (PAI-1; also known as SERPINE1, a TGF- $\beta$ /ALK5 target gene) and the inhibitor of DNA binding 1 gene (a BMP target gene) [7]. TGF- $\beta$ can also activate non-Smad pathways, including the extracellular signal-regulated kinase (ERK) mitogen-activated protein (MAP) kinase signalling pathway $[9,10]$. TGF- $\beta$ is a potent modulator of fibroblast and myofibroblast proliferation and differentiation [3,11-13]. Previous studies of DD tissue found increased protein synthesis and expression of all three TGF- $\beta$ isoforms and their receptors [14-18]. In vitro contraction assays revealed that TGF- $\beta$ stimulation generates or increases contractile force in Dupuytren-derived cells [19-23]. In addition, TGF- $\beta$ stimulation leads to upregulation of key ECM components, such as fibronectin and type I collagen (COL1), and this effect either may be direct or may occur indirectly via enhanced expression of matricellular protein connective tissue growth factor (CTGF/ CCN2) $[24,25]$. TGF- $\beta$ stimulation can also induce the expression of growth factors, such as platelet-derived growth factor (PDGF) [26].

It is not known whether BMPs play a role in DD. Compared to normal fascia-derived cells, Dupuytrenderived cells do not express BMP4 and exhibit decreased BMP6 and BMP8 expression [27]. A previous study found that there is decreased BMP receptor expression and, apparently, reduced BMP responsiveness in DD tissue, which has constrained research into BMPs as potential antagonists of TGF- $\beta$-induced fibrosis in DD as described in kidney and liver fibrosis [28].

In this study, we investigated the aberrant activation of the TGF- $\beta /$ Smad and PDGF/ERK1/2/MAP kinase pathways in DD tissue specimens and cell culture. Using BMP6 and selective chemical inhibitors of the TGF- $\beta$ receptors, the PDGF receptors and the MAP kinase pathway, we attempted to counteract the fibrogenic characteristics of DD. Our insights may contribute to the development of new therapeutic strategies for sustained, nonsurgical treatment of DD.

\section{Methods}

\section{Clinical specimens}

DD tissue specimens were obtained from four adult patients undergoing fasciectomy for DD. Patients who underwent carpal tunnel release and showed no evidence of DD contributed the control tissue from normal palmar fascia $(n=3)$ or carpal ligament $(n=1)$. All DD tissues used were from primary releases. The tissue was separated macroscopically in nodules and cords. Only nodules were used in this study. For details on how samples were prepared, see the Additional files.

\section{Clinical sample preparation}

After excision, the nodule was divided in three portions. One portion was placed in $10 \%$ formalin and further processed for immunohistochemistry. The second was immediately placed into liquid nitrogen for protein extraction. The third portion was used for primary cell culture. All of the patients underwent excision independently of this study and had not undergone previous surgery on their hands. Oral consent for removal of the tissue and storage in the tissue bank for research purposes was obtained from the patients. Individual consent for this specific project was waived by the local ethics committee because the research was performed on 'waste' material, which was stored in a coded fashion.

\section{Reagents}

Recombinant human TGF- $\beta 3$ (OSI Pharmaceuticals Inc., Melville, NY, USA) and recombinant human BMP6 (Creative BioMolecules, Hopkinton MA, USA) were generously provided by K Iwata and K Sampath, respectively. SB431542 compound, which targets ALK4, ALK5 and ALK7, was purchased from Tocris Bioscience, Ellisville, Missouri, USA. The PD98059 compound, which targets mitogenactivated protein kinase kinase 1 (MEK1), was purchased from Cell Signaling Technology (Danvers, MA, USA). The vascular endothelial growth factor (VEGF) receptor inhibitor PTK787/ZK222584, the epidermal growth factor (EGF) receptor inhibitor PKI166 and the PDGF receptor inhibitor STI571 (also known as imatinib mesylate) were kindly provided by Novartis, Amsterdam, The Netherlands. The protein kinase $\mathrm{C}$ activator 12-O-tetradecanoylphorbol-13-acetate (TPA) was obtained from Sigma (Sigma Chemical Co., St. Louis, MO, USA).

\section{Cell culture}

To obtain primary cells, tissues were minced under sterile conditions into pieces that measured approximately $1 \times 1$ 
$\times 2 \mathrm{~mm}^{3}$. Ten to twenty pieces were placed as explants into the wells of six-well plates and stored in $37^{\circ} \mathrm{C}$ incubators in $5 \% \mathrm{CO}_{2}$. Primary cells from passages 3 through 6 were used for the experiments. All of the cells were subcultured in DMEM containing $4.5 \mathrm{~g} / \mathrm{L}$ glucose (Gibco, Breda, The Netherlands) supplemented with $10 \%$ foetal bovine serum (FBS) (Integro, Zaandam, The Netherlands), $100 \mathrm{IU} / \mathrm{mL}$ penicillin and $100 \mathrm{IU} / \mathrm{mL}$ streptomycin (Invitrogen, Breda, The Netherlands).

\section{RNA isolation and quantitative real-time PCR}

Total RNA was extracted by using the RNeasy Kit (Qiagen, Venlo, The Netherlands) according to the manufacturer's instructions. Reverse transcriptase PCR was performed using the RevertAid H Minus First Strand cDNA Synthesis Kit (Fermentas, St. Leon-Rot, Germany) according to the manufacturer's instructions. All of the samples were plated in duplicate, and TaqMan PCR reactions were performed using the StepOnePlus RealTime PCR System (Applied Biosystems, Carlsbad, California, USA). Lack of DNA contamination was verified and gene expression levels were determined using the comparative $\Delta C_{\mathrm{t}}$ method with glyceraldehyde 3-phosphate dehydrogenase (GAPDH) as the reference.

\section{Quantitative PCR primers}

Human TGF- $\beta 1$ through TGF- $\beta 3, \alpha-S M A, P A I-1, c-m y c$, COl1A2, fibronectin, Smad1 through Smad3, CTGF, $P D G F-A, P D G F-B$ and GAPDH gene expression was analysed using the following forward and reverse primers: TGF- $\beta 1,5$ '-CTCTCCGACCTGCCACAGA-3' and 5'AACCTAGATGGGCGCGATCT-3'; TGF- $\beta 2$, 5'-CCG CCCACTTTCTACAGACCC-3' and 5'-GCGCTGGG TGGGAGATGTTAA-3'; TGF- $\beta 3, \quad 5$ '-CTGGCCCT GCTGAACTTTG-3' and 5'-AAGGTGGTGCAAGTGGACAGA-3'; $\alpha$-SMA, 5'-CACCTTCCAGCAGATGTGGAT-3' and 5'-AAGCATTTGCGGTGGACAAT-3'; PAI-1, 5'-TCTTTGGTGAAGGGTCTGCT-3' and 5'-CT GGGTTTCTCCTCCTGT TG-3'; $c$-myc, 5'-CGTCTC CACACATCAGCACAA-3' and 5'-CACTGTCCAA CTTGACCCTCTTG-3'; COl1A2, 5'-GATGTTGAAC TTGTTGCTGAGG-3' and 5'-TCTTTCCCCATTC ATTTGTCTT-3'; fibronectin, 5'-GAGGCCACCATCA CTGGTT-3' and 5'-AGTGCGATGACATAGA TGGTGTA-3'; Smad1, 5'-TGAACCATGGATTTGAGA CAGT-3' and 5'-CTGGCGGTGGTATTCTGC-3'; Smad2, 5'-CGAAAAGGATTGCCACATGTT-3' and 5'TTGAGTTCATGATGACTGTGAAGATC-3'; Smad3, 5'-CGGTCAACCAGGGCTTTG-3' and 5'-CAGCCTTT GACGAAGCTCATG-3'; CTGF, 5'-TTGCGAAGCT GACCTGGAAGAGAA-3' and 5'-AGCTCGGTATG TCTTCATGCTGGT-3'; PDGF-A, 5'-CCTCACAT CCGTGTCCTCTT-3' and 5'-ACACGAGCAGTGTCAAGTGC-3'; PDGF-B, 5'-TGCTGTTGAGGTGG
CTGTAG-3' and 5'-GAAAATGCAGGGTGGAGGTA3'; TGF- $\alpha$, 5'-TAACCACGAGACCCTCAACC-3' and 5'CCCAAGCCTTAGCTGTCTTG-3'; and GAPDH, 5'-AT CACTGCCACCCAGAAGAC-3' and 5'-ATGAGGTCC ACCACCCTGTT-3'.

\section{MTS-based proliferation assay}

Cells were seeded into 96 -well plates at $7 \times 10^{3}$ cells/ well and treated the next day with the indicated inhibitors or DMSO as a control. Increases in the number of viable cells after culture were measured daily for 4 days using an 3-(4,5-dimethylthiazol-2-yl)-5-(3-carboxymethoxyphenyl)-2-(4-sulfophenyl)-2H-tetrazolium (MTS)-based proliferation assay according to the manufacturer's instructions (CellTiter 96 AQueous One Solution Cell Proliferation Assay System; Promega, Leiden, The Netherlands) and using the measured absorbance at $490 \mathrm{~nm}$ on day 0 as the reference.

\section{Tissue lysate preparation and Western blot analysis}

For tissue lysates, biopsies were frozen in liquid nitrogen and pulverised using a mortar. Thereafter, the triturated tissues were incubated in ice-cold lysis buffer (150 mmol NaCl, 20 mmol Tris. $\mathrm{HCl}, \mathrm{pH} 7.5,1 \%$ Nonidet P40, $5 \mathrm{mmol}$ sodium ethylenediaminetetraacetic acid (EDTA) and one Complete Protease Inhibitor Cocktail Tablet (Roche, Woerden, The Netherlands) per $50 \mathrm{~mL}$ of solution) for 30 minutes. Prior to centrifugation at $4^{\circ}$ $\mathrm{C}$ for 15 minutes at $14 \times 10^{3} \mathrm{rpm}$, the samples underwent extensive vortexing and sonification. The total protein content of the supernatant was determined using the DC Protein Assay (Bio-Rad Laboratories, Veenendaal, The Netherlands)). Equal amounts of total protein $(100 \mu \mathrm{g} / \mu \mathrm{L})$ were loaded onto a $10 \%$ gel, followed by SDS-PAGE and Western blot analysis. For cell-based assays, cells were plated onto six-well plates at a density of $4 \times 10^{5}$ cells/well, stimulated with the indicated reagents and directly lysed in sample buffer $(250 \mathrm{mmol}$ Tris. $\mathrm{HCl}, \mathrm{pH}$ 6.8, 8\% SDS, 40\% glycerol, $5 \% \beta$-mercaptoethanol, and bromophenol blue) after 18 hours. Antibodies specifically targeting Smad1 (Zymed, San Francisco, CA, USA), Smad2/3 (BD Transduction Laboratories, Breda, The Netherlands), phosphorylated ERK1/2 (P-ERK1/2; Cell Signaling Technology), PAI-1 (Santa Cruz Biotechnology, Santa Cruz, CA, USA), Col1 $\alpha 2$ (Col1A2; SouthernBiotech, Birmingham, Alabama, USA), $\alpha$-SMA (Sigma Chemical Co.), fibronectin/ ED-A (Abcam, Cambridge, MA, USA) and c-myc (Santa Cruz Biotechnology) were purchased. Antibodies targeting phosphorylated Smad1 and Smad2 (P-Smad1 and PSmad2, respectively) were described previously [29]. PSmad3 was obtained from E Leof (Mayo Clinic, Rochester, MN, USA), and P-ERK1/2 antibodies were a gift from WH Moolenaar (Netherlands Cancer Institute, 
Amsterdam, The Netherlands). Equal loading was confirmed using an anti- $\beta$-actin antibody (Sigma Chemical Co.). Quantitative Western blot analysis was performed using secondary goat anti-rabbit IRDye 680 and goat anti-mouse IRDye $800 \mathrm{CW}$ with the Odyssey Scanner (LI-COR Biosciences, Lincoln, Nebraska USA) according to the manufacturer's instructions.

\section{Immunofluorescence}

For immunofluorescence staining, cells were grown on coverslips overnight. Cells were fixed with ice-cold methanol for 30 minutes, washed twice with PBS, quenched with $20 \mathrm{mmol} \mathrm{NH}_{4} \mathrm{Cl}$, and permeabilised with $0.1 \%$ Triton X-100 the following day. Cells were then incubated in blocking solution (PBS containing 3.0\% BSA) for 45 minutes followed by incubation for 1 hour with anti- $\alpha$-SMA antibody (Sigma Chemical Co.) diluted 1:100 in blocking solution. After washing, the labelled secondary antibody Alexa Fluor 488 goat anti-mouse immunoglobulin G (IgG) (Invitrogen) was used. Nuclei were stained using Hoechst 33258 (Invitrogen) according to the manufacturer's instructions. Specimens were visualised by using an Olympus IX51 inverted microscope at $\times 100$ magnification using the cell ${ }^{\mathrm{F}}$ Soft Imaging System (Olympus, Zoeterwoude, The Netherlands).

\section{Immunocytochemistry}

Cells were cultured overnight on coverslips. The next day fixation in acetone followed by staining for $\alpha$-SMA ( $\alpha$-SMA/1, M851, 1A4 clone; Dako, Carpinteria, CA, USA) at 1:500 dilution was performed for 60 minutes. Endogenous peroxidase was quenched with $0.1 \%$ natriumazide/0.3\% hydrogen peroxide in PBS. After post-antibody blocking, goat poly-horseradish peroxidase (HRP) anti-mouse IgG (Immunologic, Duiven, The Netherlands) was added for 30 minutes. The colouring reaction was developed with 3-amino-9-ethylcarbazole (AEC), and counterstaining was performed with $\mathrm{H} \& \mathrm{E}$.

\section{Immunohistochemistry}

Paraffin-embedded tissue samples of $5-\mu \mathrm{m}$ thickness were sequentially cut. Before blocking endogenous peroxidase activity with $1 \%$ hydrogen peroxide (Merck, Amsterdam, The Netherlands) in 2\% PBS, sections were deparaffinised and rehydrated using xylene and a descending alcohol series. Blocking was performed with the following sequence: $2.5 \%$ periodic acid, $0.02 \%$ sodium borohydride and Protein Block (Dako).

Detection of TGF- $\beta 3$ : After deparaffinisation, antigen retrieval was performed in citrate buffer. Blocking was done with Protein Block (Dako) for 20 minutes. TGF- $\beta 3$ antibody (Abcam) was applied overnight in a humid chamber at $4^{\circ} \mathrm{C}$. Slides were rinsed in PBS, after which biotinylated link antibody was added (LSAB2 System;
Dako) for 60 minutes. After slides were washed in PBS, streptavidin conjugate (LSAB2 System) was applied for 60 minutes.

Detection of P-Smad2: Prior to the application of Protein Block for 20 minutes, sections were pretreated with proteinase $\mathrm{K}(2 \mu \mathrm{g} / \mathrm{mL}$ in $\mathrm{PBS})$ at $37^{\circ} \mathrm{C}$ for 30 minutes. P-Smad2 (Ser465/467; Cell Signaling Technology) was added overnight in a humid chamber at $4^{\circ} \mathrm{C}$. Slides were rinsed in PBS, after which biotinylated link antibody was added (LSAB2 System) for 60 minutes. After PBS washing, streptavidin conjugate (LSAB2 System) was applied for 60 minutes.

Detection of $\alpha$-SMA: After quenching endogenous peroxidase activity with $0.3 \% \mathrm{H}_{2} \mathrm{O}_{2}$ in methanol, slides were heated in Tris-EDTA for 10 minutes at $100^{\circ} \mathrm{C}$ for antigen retrieval. The $\alpha$-SMA antibody ( $\alpha$-SMA/1, M851, 1 A4 clone; Dako, Glostrup, Denmark) was applied for 60 minutes followed by post-antibody blocking (Immunologic) for 15 minutes. After rinsing, goat poly-HRP against mouse IgG (Immunologic) was added for 30 minutes followed by PBS washing. All colouring reactions were developed by using 3,3'-diaminobenzidine (Sigma Chemical Co.) followed by counterstaining with $\mathrm{H} \& \mathrm{E}$. Unlabelled samples were scored by an independent pathologist. Scoring was rated as follows: no staining (-) (except for staining in blood vessel walls), weak staining $(+)$, moderate staining $(++)$ and intense staining $(+++)$.

Detection of P-ERK1/2: Before blocking endogenous peroxidase activity with $40 \%$ methanol and $1 \% \mathrm{H}_{2} \mathrm{O}_{2}$ (Merck) in PBS, sections were deparaffinised and rehydrated using xylene and a descending alcohol series. Antigen retrieval using proteinase $\mathrm{K}(2.5 \mu \mathrm{L}$ in 100 mmol Tris, $\mathrm{pH} 9.0$, and 50 mmol EDTA, $\mathrm{pH} 8.0$ ) for 10 minutes at $37^{\circ} \mathrm{C}$ was followed by three washes with 0.1 mol Tris-buffered saline ( $\mathrm{pH} 7.4$ ) containing $0.02 \%$ Tween 20 (TBST). Thereafter slides were incubated in 0.5\% (Boehringer, Ingelheim, Germany) blocking reagent (BMP) in TBST for 60 minutes at $37^{\circ} \mathrm{C}$. Subsequently, the P-ERK1/2 antibody (1:100; Cell Signaling Technology) diluted in $0.5 \% \mathrm{BMP} / \mathrm{TBST}$ was applied overnight at $4^{\circ} \mathrm{C}$. Next, a species-specific biotinylated anti-IgG antibody ( $1: 600$ dilution in $0.5 \% \mathrm{BMP} / \mathrm{TBST}$ ) was applied, followed by 45 minutes at $37^{\circ} \mathrm{C}$. Incubation with streptavidin-HRP (1:200 dilution in $0.5 \% \mathrm{BMP} /$ TBST) for 30 minutes at $37^{\circ} \mathrm{C}$ preceded and followed an amplification step using biotinyl-tyramide. Staining was carried out using AEC (Sigma Chemical Co., Zwijndrecht, The Netherlands) and Mayer's haematoxylin (Merck) according to the manufacturers' instructions. A water-based mounting solution was applied, and staining was visualised by using an Olympus IX51 inverted microscope equipped with the cell ${ }^{F}$ Soft Imaging System (Olympus). Unlabelled samples were scored by an independent researcher. 
Fibroblast-populated collagen lattice contraction assay Three-dimensional fibroblast-populated collagen lattice (FPCL) contraction assays were carried out with primary cell cultures from passages 4 through 6 . The assay was performed as described previously by others, with some modifications [30-32]. The collagen lattices were prepared by mixing a neutralising solution of COL1 (eight parts $3 \mathrm{mg} / \mathrm{mL}$ COL1 (PurCol ${ }^{\circledR}$, Daiichi Sankyo, Parsippany, New Jersey, USA) one part $10 \times \alpha$-MEM (Invitrogen) and one part HEPES (4-(2-hydroxyethyl)-1piperazineethanesulfonic acid) buffer, pH 9.0). Final collagen and cell concentrations were adjusted to $2 \mathrm{mg} / \mathrm{mL}$ and $86 \times 103$ cells $/ \mathrm{mL}$ using PBS, respectively. The cellcollagen mixture was aliquoted into PBS $+2 \%$ BSA-pretreated 24-well culture dishes $(0.5 \mathrm{~mL} /$ well $)$ and left to polymerise for 1 hour at $37^{\circ} \mathrm{C}$. In each well, to the top of the polymerised lattice, we added $0.5 \mathrm{~mL} /$ well of DMEM containing 10\% FBS. After 2 days of incubation at $37^{\circ} \mathrm{C}$, the attached FPCLs were mechanically released from the sides of the culture plates, and fresh media supplemented with $0.5 \% \mathrm{FBS}$ and the indicated substances were added. Images were obtained at various time points over a 5-day period using the Odyssey Scanner (LI-COR Biosciences). Collagen lattice areas were measured using the corresponding Odyssey 2.1 software.

\section{Statistical analysis}

Values are expressed as means \pm standard error of the mean. For statistical comparisons of two samples, an unpaired, a two-tailed Student's $t$-test with distinction of equal and unequal variances in a group (Levene's test) was used to determine the significance of differences between means. In addition, a nonparametric MannWhitney $U$ test under the null hypothesis that the distributions of both groups (control versus Dupuytrenderived fibroblasts) were equal was performed for the data set shown in Figure 2C. All of the relevant comparisons were considered to be significantly different at $P<$ 0.05. Experiments were performed at least three times, and representative results are shown.

\section{Results}

\section{TGF- $\beta /$ Smad signalling upregulated in DD}

To evaluate the presence of TGF- $\beta$ signalling in DD, nodules from the palmar fascia of four DD patients were surgically removed and compared to normal palmar fascia from four control patients who had undergone carpal tunnel release surgery (Table 1). Previous studies had shown an increase in TGF- $\beta 1$ levels in DD; we extended these studies by examining TGF- $\beta 3$, and also examined P-Smad2 as a measure for active canonical TGF- $\beta$ signalling and $\alpha$-SMA as a marker for myofibroblasts. Immunohistochemical staining of the normal fascia revealed weak TGF- $\beta 3$ and P-Smad 2 signals and no $\alpha$-SMA
Table 1 Overview of patients' details

\begin{tabular}{lccc}
\hline Patients & Age, years & Gender & Tissue \\
\hline Control 1 & 63 & Female & Palmar fascia \\
Control 2 & 32 & Female & Carpal ligament \\
Control 3 & 67 & Male & Palmar fascia \\
Control 4 & 38 & Female & Palmar fascia \\
Dupuytren 1 & 56 & Female & Palmar fascia \\
Dupuytren 2 & 43 & Male & Palmar fascia \\
Dupuytren 3 & 71 & Male & Palmar fascia \\
Dupuytren 4 & 47 & Male & Palmar fascia \\
\hline
\end{tabular}

expression (except for pericytes in blood vessels). This finding is in contrast to the tissues derived from DD patients, which displayed strong staining for TGF- $\beta 3$, PSmad2 and $\alpha$-SMA. A high viable cell density, which is indicative of the proliferative stage of the cords, was confirmed with $\mathrm{H}$ \& $\mathrm{E}$ staining (Figure 1A and Table 2).

Tissue samples were further investigated for active TGF$\beta$ signalling and for protein expression of key ECM components induced during fibrogenesis (Figure 1B). On average, Smad2 and Smad3 protein expression levels were significantly upregulated in DD patients compared to $\beta$ actin protein expression levels. Furthermore, we detected an increase in P-Smad2, but not P-Smad3, when normalised to total Smad2 and Smad3, respectively, in DD patients versus controls (Figure 1B and Additional file 1, Supplementary Figure 1). In contrast, Smad1 protein expression levels did not differ between control and DD patient material. P-Smad1 was not detected in control or DD samples (data not shown). Fibrogenesis ECM markers, such as COL1 and fibronectin/ED-A, were detectable in DD tissue but not in control samples. The myofibroblast marker $\alpha$-SMA was strongly upregulated in all four DD patients (Figure 1B).

We next examined whether primary fibroblasts derived from the tissue samples described above had similar properties. We first investigated the presence of all three TGF- $\beta$ isoforms. In particular, the mRNA expression of the TGF- $\beta 1$ and TGF- $\beta 3$ isoforms was significantly upregulated in primary fibroblasts derived from DD tissue samples, whereas TGF- $\beta 2$ mRNA expression was barely detectable (Figure 2A). Consistent with the results of the immunohistochemistry performed on the tissue samples, cultured Dupuytren's fibroblasts stained positive for $\alpha$ SMA protein expression, whereas the control fibroblasts contained only very little $\alpha$-SMA protein expression. The percentages of myofibroblasts in DD versus control patients was $40 \%$ to $50 \%$ versus $2 \%$ to $5 \%$ (Figure $2 \mathrm{~B}$ ).

We then quantitatively compared the mRNA expression levels of components involved in TGF- $\beta$ signalling and fibrosis. On average, a nonparametric Mann-Whitney $U$ test (data not shown) followed by an unpaired Student's $t$-test revealed that Smad2 and Smad3 mRNA 
expression, as well as expression of the TGF- $\beta$ target genes $P A I-1$ and $C T G F$, were significantly upregulated in Dupuytren's fibroblasts compared to control fibroblasts. mRNA expression of the ECM component COL1, $\alpha 2(C O L 1 A 2)$ gene and the cytoskeleton representative $\alpha$-SMA were also significantly increased, whereas the expression of fibronectin mRNA did not differ from that of control cells. The BMP signalling intracellular component Smad1 was present at lower levels in Dupuytren cells compared to normal fascia-derived cells (Figure 2C). The fact that the null hypothesis of the Mann-Whitney $U$ test of equal distribution of control (patients 1 through 4) and Dupuytren-derived (patients 1 through 4) fibroblasts was rejected in $87.5 \%$ of the tested samples because we concluded that both control and Dupuytren-derived fibroblasts have an independent mRNA expression profile that also allows for statistical comparison, which furthermore allows the statistical analysis of pooled cell samples. Taken together, these results suggest that TGF- $\beta /$ Smad signalling is increased in this fibroproliferative disease.

\section{SB-431542 inhibited fibrogenic properties of Dupuytren's fibroblasts}

Because TGF- $\beta$ signalling was proposed to play an important role in the etiopathogenesis of DD, we investigated the expression of TGF- $\beta$ isoforms and the involvement of TGF- $\beta$-like signalling in the fibrogenic characteristics of the disease. We observed that TGF- $\beta 1$ and TGF- $\beta 3$ mRNA were expressed at much higher levels in Dupuytren's than in control fibroblasts (Figure 3A), and we noted
Table 2 Evaluation of immunohistochemical staining ${ }^{a}$

\begin{tabular}{lccc}
\hline Patients & TGF- $\beta 3$ & P-Smad2 & $\alpha$-SMA \\
\hline Control 1 & + & ++ & - \\
Control 2 & ++ & ++ & - \\
Control 3 & + & ++ & - \\
Control 4 & + & - & - \\
Dupuytren 1 & +++ & ++ & ++ \\
Dupuytren 2 & +++ & +++ & +++ \\
Dupuytren 3 & +++ & +++ & +++ \\
Dupuytren 4 & +++ & ++ & +++ \\
\hline
\end{tabular}

${ }^{a}$ Evaluation of immunohistochemical staining was performed on four control and four Dupuytren tissue samples. Positivity was graded on a scale from (-) to $(+++)$, with $(-)$ representing no staining, $(+)$ representing weak staining, (+ + ) representing moderate staining and $(+++)$ representing strong staining. Staining in blood vessels was not included. The scoring was performed on unlabelled samples by a pathologist not involved in the study. Representative images are shown in Figure $1 \mathrm{C}$.

a strong reduction in the elevated $\alpha$-SMA expression in Dupuytren's fibroblasts upon treatment with SB-431542 (Figures 3B and 3C). Importantly, SB-431542 had strong inhibitory effects in the collagen contraction assay on both control and Dupuytren's cells (Figure 3C and Additional file 2, Supplementary Figure 2). Our data indicate that the self-induced basal contraction of Dupuytren's cells was caused by increased endogenous TGF- $\beta$-like Smad signalling, which enhanced $\alpha$-SMA expression and promoted collagen contraction (Figure 3).

\section{BMP6 attenuated TGF- $\beta$ signalling in Dupuytren's fibroblasts}

Because it has been suggested that BMPs, particularly BMP7, can counteract TGF- $\beta$-induced fibrosis in the
A

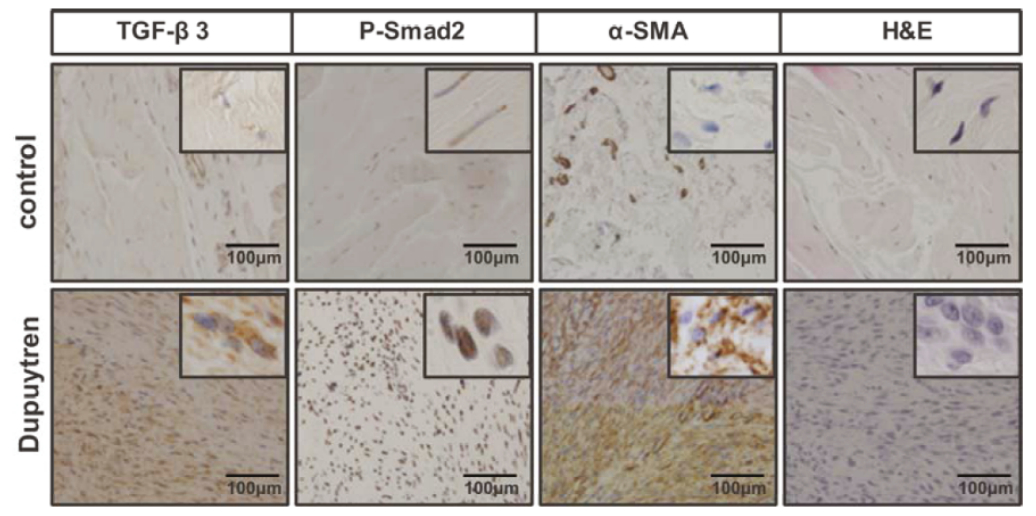

B

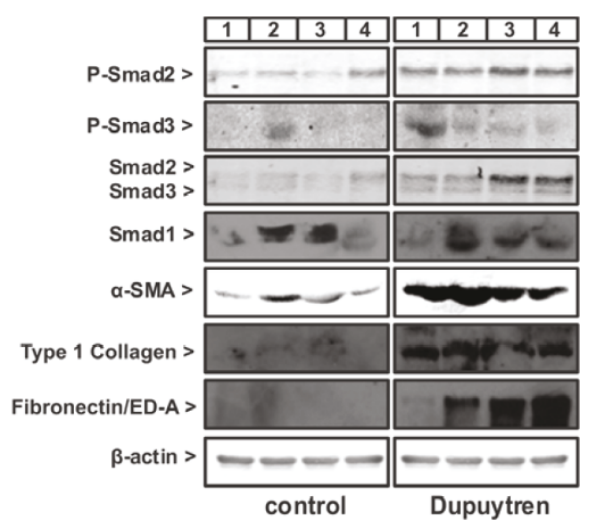

Figure 1 Characterisation of Dupuytren's disease and control tissue specimens. (A) Immunostaining of Dupuytren's disease (DD) and control tissue specimens for transforming growth factor $\beta 3$ (TGF- $\beta 3$ ), phosphorylated Smad2 (P-Smad2), $\alpha$-smooth muscle actin ( $\alpha$-SMA) and H \& E. Representative staining from DD patient 4 and control patient 1 is shown. Insets within each image are higher-magnification views. Evaluation of all four control and DD tissue samples are described in Table 2. (B) Protein expression analysis for P-Smad2; phosphorylated Smad3 (P-Smad3); total Smad2, Smad3 and Smad1; $\alpha$-SMA; type I collagen; and fibronectin/ED-A by Western blot analysis of $100 \mu \mathrm{g}$ of total protein extract isolated from four individual control patient-derived and four individual DD patient-derived tissue samples. $\beta$-actin was used as a loading control. 


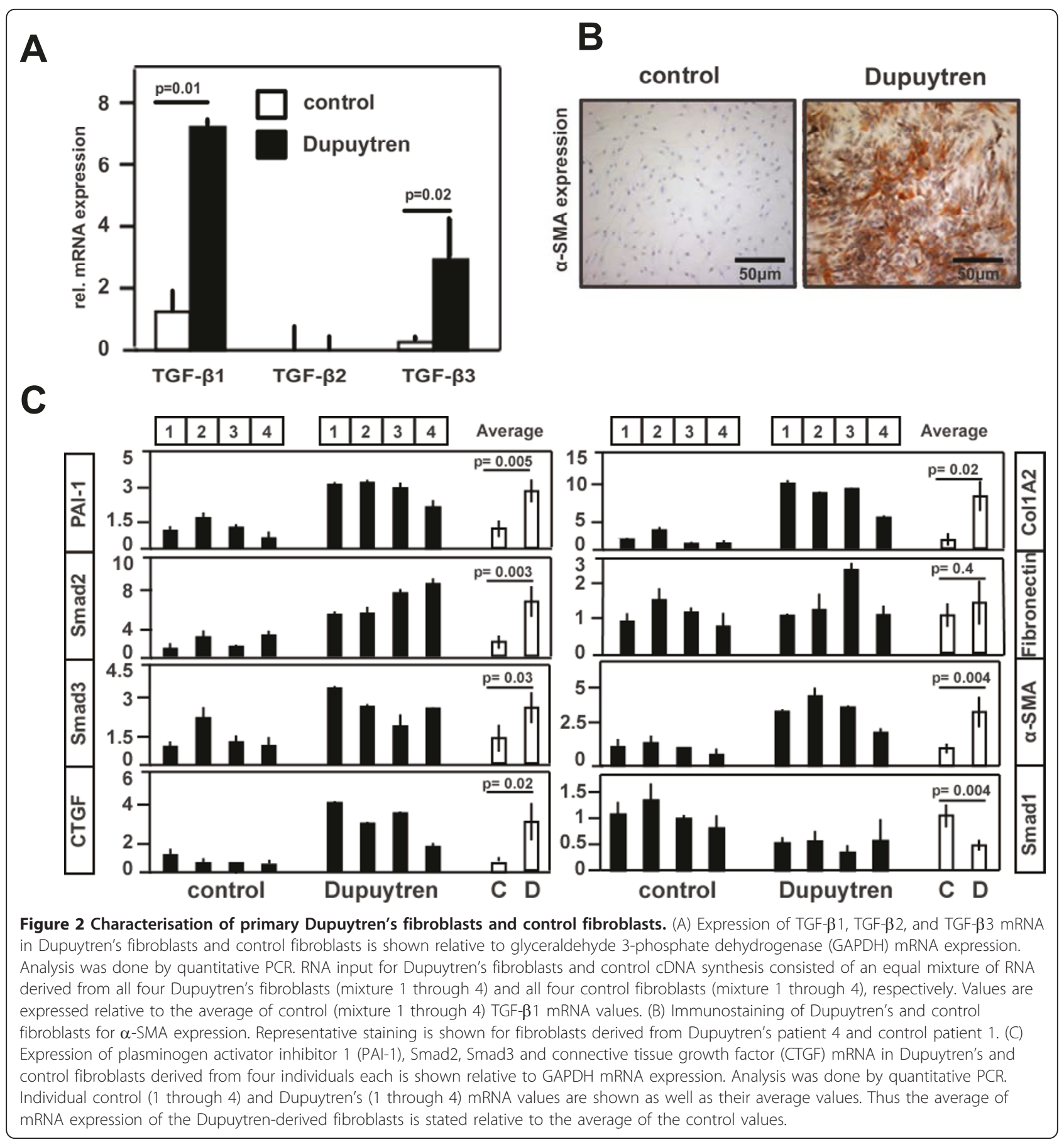

kidney, lung and liver, we investigated the effect of BMPs on Dupuytren's fibroblasts. BMP6, but not BMP7, attenuated endogenous TGF- $\beta$-like signalling. Quantitative PCR revealed that BMP6 strongly induced TGF- $\beta 1$ mRNA expression in control cells but left the expression of the TGF- $\beta 2$ and TGF- $\beta 3$ isoforms unaffected (Figure $3 \mathrm{~A})$. In contrast to the control cells, in Dupuytren's fibroblasts BMP6 counteracted TGF- $\beta 1$ and TGF- $\beta 3$ mRNA expression (Figure 3A) and reduced SMAD2 and
SMAD3, but not SMAD1, mRNA expression (data not shown).

As predicted on the basis of its antagonistic effects on TGF- $\beta$-like signalling, BMP6 (but not BMP7) attenuated $\alpha$-SMA expression and counteracted the spontaneous elevated contraction seen in Dupuytren's fibroblasts (Figures 3B to 3D and Additional file 2, Supplementary Figure 2; data not shown). This inhibitory effect of BMP6 was further potentiated by simultaneous 


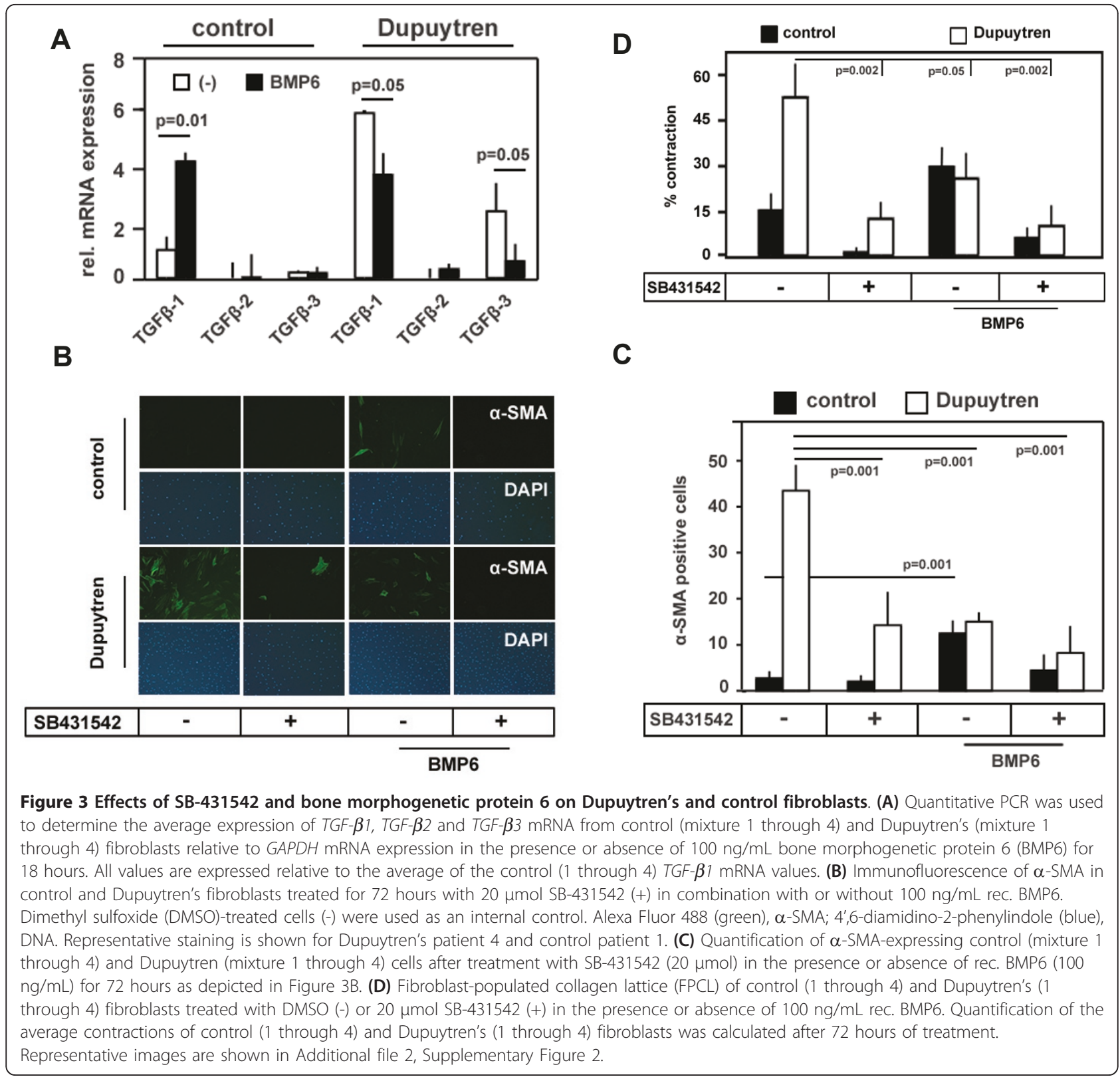

treatment with SB-431542 (Figures 3C and 3D and Additional file 2, Supplementary Figure 2).

\section{ERK1/2/MAP kinase signalling elevated in DD}

It has been shown that TGF- $\beta$ can activate non-Smad signalling pathways, such as MAP kinase signalling $[9,10]$. In addition, MAP kinases are activated by growth factors such as PDGF that have been implicated in DD $[33,34]$. We therefore investigated the phosphorylation of p38, c-Jun N-terminal kinase (JNK) and ERK in control and Dupuytren's tissue samples as well as in primary cells. While we did not detect phosphorylation of p38 and JNK (data not shown), phosphorylation of
ERK1/2 was significantly increased in Dupuytren's tissue samples compared to control samples (Figures 4A and $4 B)$. Similar results were obtained with fibroblasts isolated from Dupuytren's and control patients (Figures 4C and $5 \mathrm{~A})$.

We next determined the direct effects of TGF- $\beta$ on the phosphorylation of ERK1/2 in Dupuytren's fibroblasts. We found that 5 minutes of TGF- $\beta 3$ treatment induced a further increase in the phosphorylation of ERK1/2, which was inhibited by SB-431542 to a level lower than the basal level (Figure 4C). The presence of BMP6, however, had only marginal effects on the direct TGF- $\beta 3$-induced phosphorylation of ERK1/2 (Figure 4C). In addition to its 


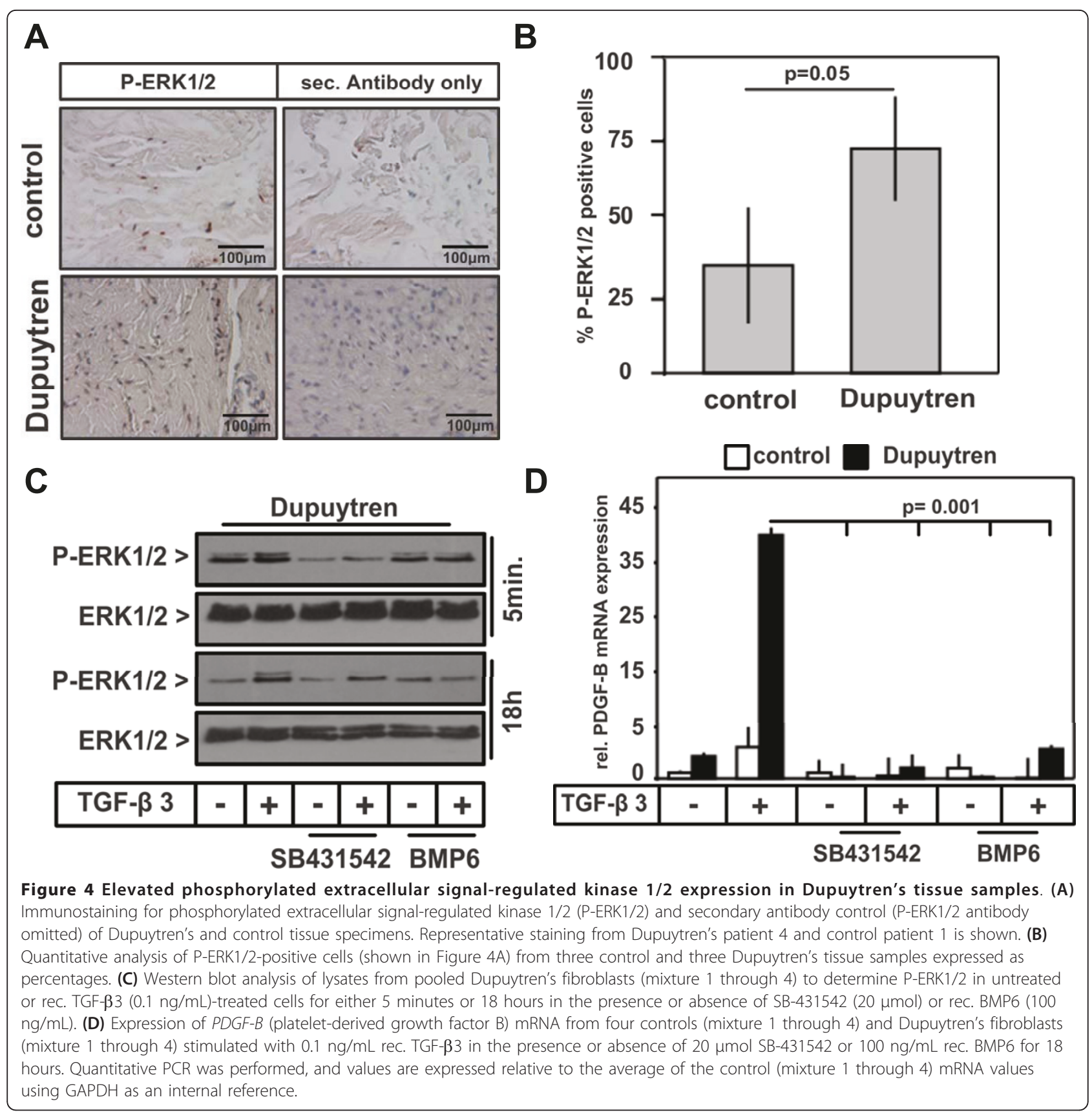

direct effect, TGF- $\beta 3$ also induced an increase in ERK1/2 phosphorylation after 18 hours of stimulation. Interestingly, while SB-431542 showed only marginal effects on this sustained activation, BMP6 strongly attenuated this effect after 18 hours (Figure 4C).

The sustained effect of TGF- $\beta 3$ on ERK $1 / 2$ was likely indirect and may have occurred via the TGF- $\beta$-mediated induction of growth factors. Indeed, $P D G F-B$ and $P D G F-A$ mRNA expression in particular were significantly upregulated in Dupuytren's fibroblasts and were strongly induced by TGF- $\beta 3$ treatment (Figure 4D and data not shown). SB-431542 compound or BMP6 counteracted the TGF- $\beta$-induced increase in PDGF- $B$ mRNA expression (Figure 4D).

\section{Targeting of TGF- $\beta$ type I receptor and ERK1/2/MAP} kinase pathways in Dupuytren's fibroblasts

We next set out to determine whether the elevated TGF- $\beta /$ Smad and MAP kinase signalling pathways were causally linked to an increase in the expression of key fibrotic and proliferation proteins by interfering with these pathways using the ALK4, ALK5 and ALK7 


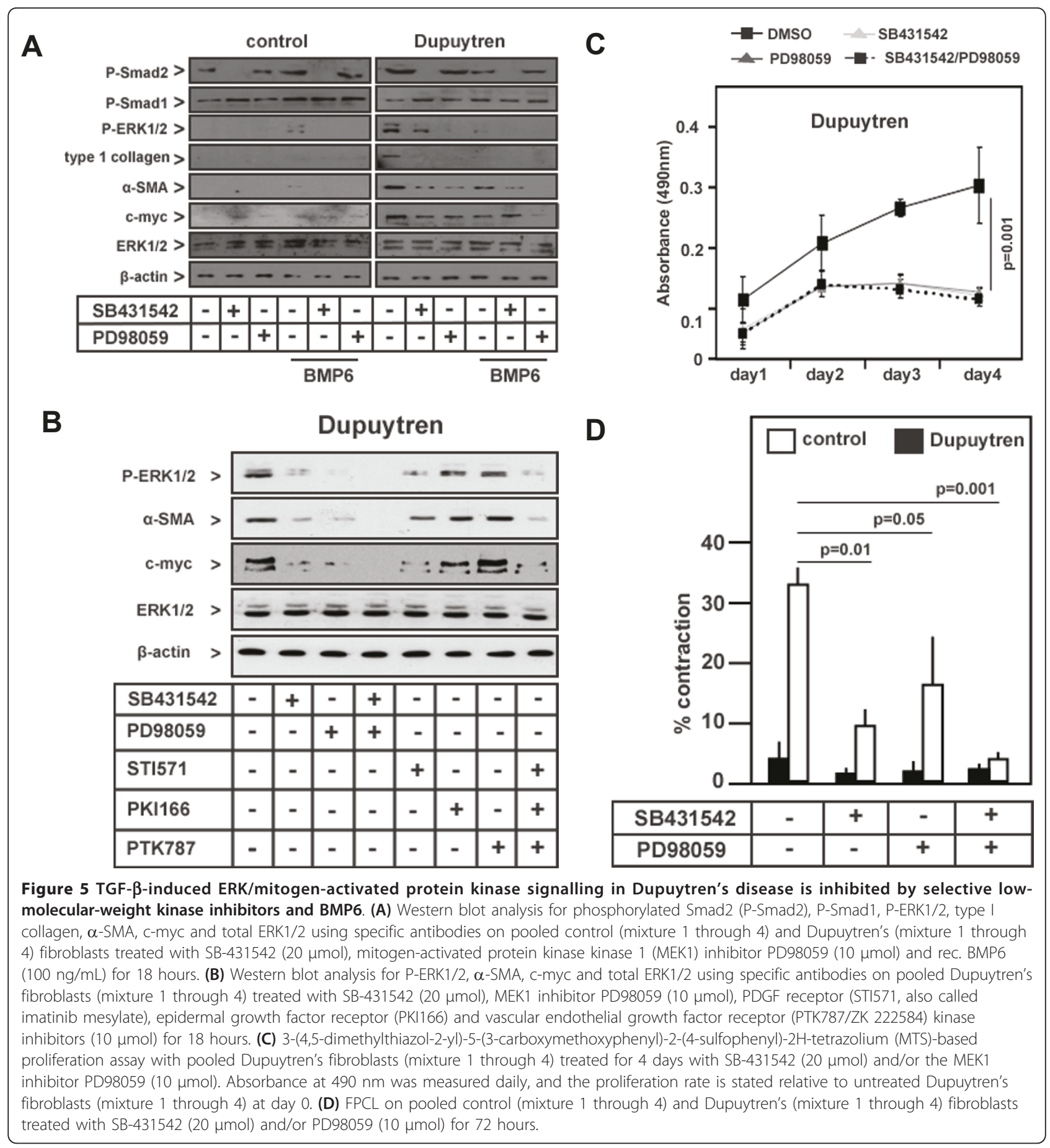

inhibitor SB-431542 [8,30], the MEK1 inhibitor PD98059 [35] and BMP6. Treatment of Dupuytren's fibroblasts with SB-431542 completely inhibited elevated basal P-Smad2 levels and also attenuated P-ERK1/2 levels. This suggests that these increased basal activities are due to TGF- $\beta$ or TGF- $\beta$-like ligands that are secreted by Dupuytren's fibroblasts themselves. PD98059 also strongly inhibited elevated basal P-ERK1/2 levels and had no significant effect on P-Smad2 levels (Figure $5 \mathrm{~A})$. Both treatments were associated with decreased expression of fibrotic marker proteins such as COL1 and $\alpha$-SMA and reduced expression of the proliferation marker c-myc proto-oncogene (Figure 5A). Both SB431542 and PD98059 treatment also inhibited COL1A2, CTGF and PAI-1 gene expression (Additional file 3, Supplementary Figure 3). The inhibitory effects of SB- 
431542 or PD98059 were potentiated by cotreatment with BMP6 (Figure 5A). Cotreatment with SB-431542/ BMP6 and PD98059/BMP6 combinations decreased the levels of P-ERK1/2, COL1 and $\alpha$-SMA to undetectable levels in Dupuytren's cells, which also was seen in untreated control cells. The c-myc level was significantly downregulated by PD98059/BMP6 and reached the low levels observed in control cells (Figure 5A).

We found that TGF- $\beta 3$ strongly induced PDGF (Figure 4D), which, via its receptor, can activate ERK1/2/ MAP kinase signalling. To determine the role of PDGF signalling in the augmented ERK1/2 phosphorylation observed in DD, we treated Dupuytren's fibroblasts with a selective PDGF receptor tyrosine kinase inhibitor (STI571, also known as imatinib mesylate) [36] and compared its effect with the effects of the inhibitors SB431542 and PD98059. EGF receptor and VEGF receptor tyrosine kinase inhibitors $[37,38]$ were used as specificity controls for the PDGF receptor kinase inhibitor. The PDGF receptor kinase inhibitor led to strong but incomplete decreases in ERK1/2 phosphorylation and c-myc expression (Figure 5B). Its effect was weaker than cotreatment of Dupuytren's fibroblasts with SB-431542 and PD98059. The EGF and VEGF receptor kinase inhibitors showed only minor effects. We could find no significant inhibition of the elevated $\alpha$-SMA expression upon challenge of Dupuytren's fibroblasts with STI561 (Figure 5B), however, which is consistent with previous findings that link PDGF to proliferation and not to a myofibroblast transdifferentiation response [39].

The inhibitory effects of PD98059 suggest that the ERK1/2 MAP kinase pathway plays an important role in the increased fibrotic characteristics of Dupuytren's fibroblasts compared to control fibroblasts. When we stimulated Dupuytren's fibroblasts with TPA, which activates ERK1/2/MAP kinase pathways (as well as other pathways), we found elevated $\alpha$-SMA expression and collagen contraction (Additional file 4, Supplementary Figure 4). Thus, ERK/MAP kinase signalling may be sufficient to weakly mediate the fibroproliferative properties observed in Dupuytren's fibroblasts.

Taken together, our results indicate that both the TGF- $\beta /$ Smad and ERK1/2 MAP kinase signalling pathways contribute to the fibrogenic responses of Dupuytren's fibroblasts. We therefore determined whether we could normalise the fibroproliferative characteristics of Dupuytren's fibroblasts by targeting TGF- $\beta$-like signalling and ERK1/2/MAP kinase with SB-431542 and the MEK1 inhibitor PD98059, respectively. Concurrent treatment of Dupuytren's fibroblasts with SB-431542 and PD98059 abrogated ERK1/2 phosphorylation as well as $\alpha$-SMA and c-myc expression (Figure $5 \mathrm{~B}$ ). Consistent with this observation, we found that treatment with SB431542 and/or PD98059 strongly inhibited the elevated basal proliferation of Dupuytren's fibroblasts and had only minor effects on the proliferation rate of normal fibroblasts (Figure 5C and Additional file 5, Supplementary Figure 5). The high spontaneous contraction rate in Dupuytren's fibroblasts was completely blocked by cotreatment with SB431542 and PD98059 (Figure 5D).

\section{Discussion}

DD is a chronic, fibroproliferative disorder that is most likely induced by overactive cytokines such as TGF- $\beta$, which is thought to play a prominent role by stimulating Dupuytren's fibroblasts to produce excessive levels of ECM proteins and by promoting their contractile phenotype [1]. In line with the results of previous studies, we found that biopsies and fibroblasts derived from primary cultures from affected areas in patients with DD had elevated expression levels of TGF- $\beta$, in particular the TGF- $\beta 1$ and TGF- $\beta 3$ isoforms, and that this correlated with increases in the expression levels of SMA, CTGF, fibronectin and collagen in Dupuytren's fibroblasts compared to controls [18,21].

TGF- $\beta$ can signal via the Smad signalling pathways. We observed that patients with DD showed elevated expression of Smad2 and Smad3, but not Smad1. Of note, whereas P-Smad2 levels were found to be elevated, this was not clear for P-Smad3 levels. Smad2 and Smad3 may have distinct roles. In a recent article, investigators demonstrated that $\mathrm{Smad} 3$ is a negative regulator of $\alpha$-SMA expression and the activation of the myogenic program in the epithelium [40]. When we challenged Dupuytren's fibroblasts with SB-431542, which inhibits TGF- $\beta$-like signalling pathways, the expression of key fibrotic markers such as PAI-1, CTGF, $\alpha$-SMA and COL1 was decreased. Previous characterisation of the promoters of these target genes showed that they are regulated in a Smad-dependent manner [41,42]. Moreover, application of SB-431542 revealed that the high amount of spontaneous contraction of Dupuytren's fibroblasts, when embedded in a collagen lattice, was caused by overactive TGF- $\beta$-like signalling. TGF- $\beta$ receptor kinase inhibitors have been shown to inhibit fibrotic responses in other cells in vitro and in vivo [29].

In recent years, a strong link has been established between TGF- $\beta$-induced fibrosis and BMP expression and signalling. Challenging the fibrogenic properties of Dupuytren's fibroblasts with BMP6 inhibited the gene expression of TGF- $\beta 1$ and TGF- $\beta 3$ and their respective downstream Smad2 and Smad3 effectors. Whereas previous studies attributed antifibrotic effects to BMP7, a close homolog of BMP6 [28], we were unable to demonstrate this for Dupuytren's fibroblasts. One could speculate whether BMP6 could compete with TGF- $\beta$ for the recruitment of distinct receptors, thereby limiting TGF$\beta$ activity. Our data suggest a novel level of cross-talk, 


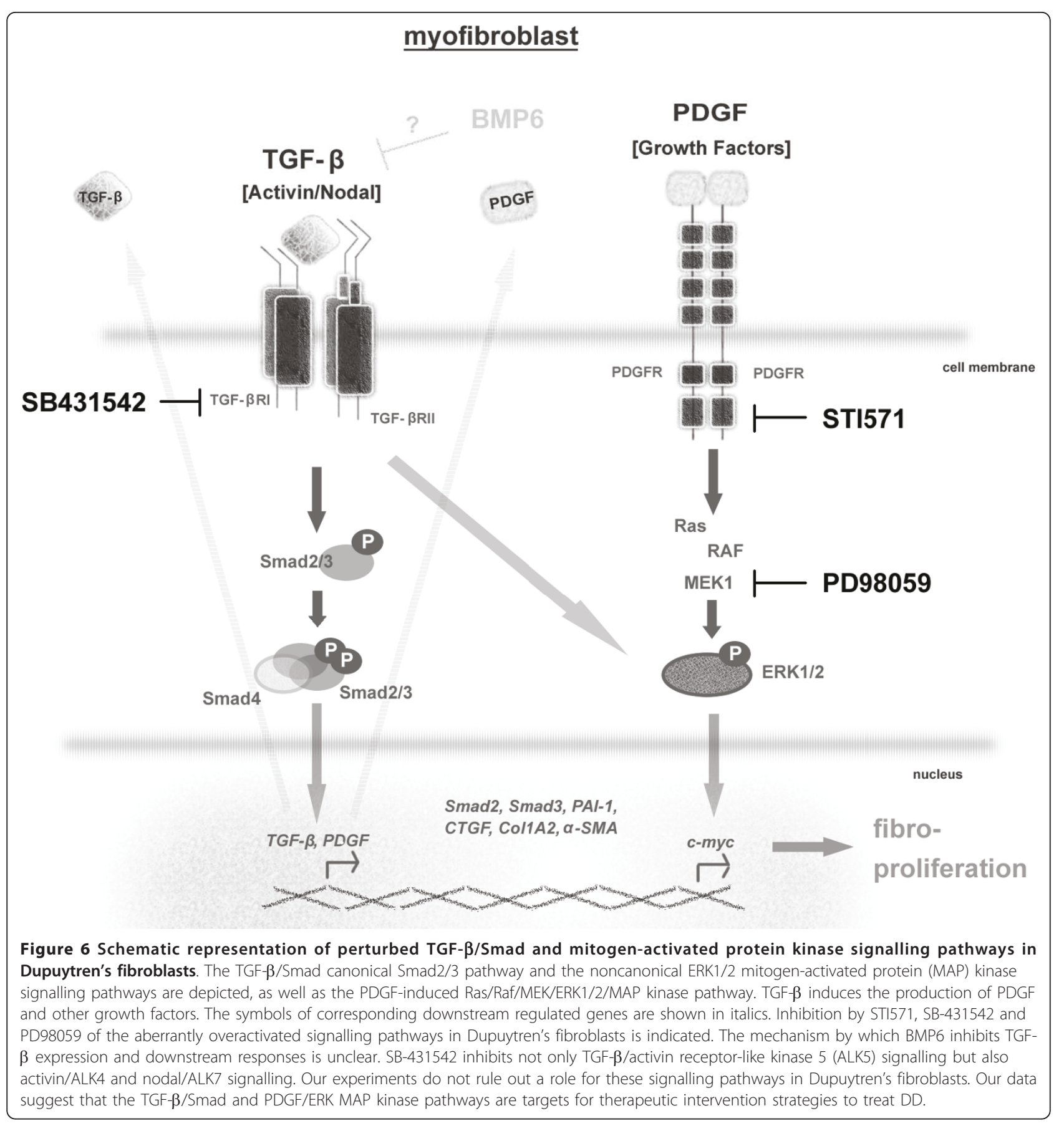

as previous studies have suggested that BMPs had an inhibitory effect on the TGF- $\beta /$ Smad pathway through the formation of mixed Smad1/5-Smad2/3 complexes $[43,44]$. It is interesting that BMP6 in particular had an antagonising effect on TGF- $\beta$-driven DD, because it has been shown that myofibroblast progenitor cells derived from patients with diabetes are deficient in BMP6 expression [45], and there is some evidence of a relationship between diabetes and DD [46]. In another study, BMP6 and BMP7 were found to have differential effects on chemotaxis via a Smad4-independent, phosphoinositide 3-kinase-dependent pathway [47]. It would be worthwhile to explore whether similar mechanisms are of relevance in Dupuytren's fibroblasts. Although BMP6 may inhibit fibrotic responses, in discussing it as a potential therapeutic agent, one needs to take into account BMP6's action on normal fibroblasts and its strong osteoinductive properties [48]. 
We found that Dupuytren's fibroblasts displayed overactive ERK1/2 signalling, but neither the JNK nor the p38 MAP kinase signalling pathway showed increased activity. This could be due to both direct TGF- $\beta$ induced ERK1/2 phosphorylation, since it was observed within 5 minutes and inhibited by SB431542, and indirectly through the induction of PDGF expression, which can stimulate ERK1/2 phosphorylation (schematically represented in Figure 6). Consistent with the latter idea, we found that treatment with the PDGF receptor inhibitor STI571 strongly mitigated the expression of phosphorylated ERK1/2.

The elevated ERK1/2 MAP kinase pathway could be linked to the elevated fibroproliferative characteristics of Dupuytren's fibroblasts. Treatment of cells with PD98059 inhibited the expression of fibrotic and proliferation markers. A role for MAP kinase signalling, also in cooperation with the Smad pathway, has been described for many TGF- $\beta$ target genes [49-52]. In line with its potent inhibitory effects on fibroproliferative markers, spontaneous collagen contraction and elevated proliferation were inhibited by PD98059. Moreover, the finding that TPA induced ERK1/2 phosphorylation and collagen contraction suggests that activation of this pathway may be sufficient to induce contraction. BMP6 was not able to counteract this TPA-induced ERK response, which is in line with its proposed inhibitory actions further upstream at the level of TGF- $\beta$ and Smad expression. Consistent with our results, inhibition of ERK1/2 MAP kinase signalling has been shown to mitigate fibrotic responses in scleroderma [53,54]. Our observations suggest a role for elevated PDGF signalling in promoting the proliferation of Dupuytren's fibroblasts. Of note, overactive PDGF signalling has been implicated in fibrosis in multiple tissues [55-57], and treatment with PDGF receptor kinase inhibitors has been shown to inhibit fibrosis [58,59].

Importantly, when both TGF- $\beta$ receptors and ERK1/2 pathways were inhibited in Dupuytren's fibroblasts through simultaneous application of SB-431542 and PD98059, a complete block of the elevated basal proliferation and contraction was observed, which in turn commuted the Dupuytren's fibroblast phenotype into 'normal' fibroblasts.

\section{Conclusions}

Both the TGF- $\beta$ and ERK1/2 MAP kinase pathways cooperated in mediating the enhanced proliferation and high spontaneous contraction of Dupuytren's fibroblasts. Taken together, our data indicate that the TGF- $\beta /$ Smad and ERK1/2 MAP kinase pathways are prime targets for the development of nonsurgical intervention strategies to treat patients with DD. For example, concurrent topical application of inhibitors such as SB-431542 and
PD98059 into the DD area could block fibroproliferative responses and recurrence in DD while preventing the potential problems associated with systemic administration of such compounds (schematically represented in Figure 6).

\section{Additional material}

\begin{abstract}
Additional file 1: Quantification of total Smad and phosphorylated Smad (P-Smad) protein expression levels as depicted in Figure 1B. Quantification was performed by densitometric analysis using the Odyssey system (LI-COR Biosciences). All values are expressed relative to $\beta$-actin protein expression levels (C, Control; D, Dupuytren).

Additional file 2: Fibroblast-populated collagen lattice (FPCL) of controls' (1 through 4) and Dupuytren's patients' (1 through 4) fibroblasts treated with dimethyl sulfoxide (DMSO) (-) or $20 \mu \mathrm{mol}$ SB-431542 (+) in the presence or absence of $100 \mathrm{ng} / \mathrm{mL} \mathrm{rec}$. bone morphogenetic protein 6 (BMP6). Corresponding images demonstrating the quantification of contraction in Figure 3D are shown.

Additional file 3: Quantitative PCR was used to determine the average expression of $\alpha$-SMA, Smad1, Smad2, Smad3, PAl-1 (plasminogen activator inhibitor 1), fibronectin, CTGF, c-myc and COL1A2 mRNA from control (mixture 1 through 4) and Dupuytren's (mixture 1 through 4) fibroblasts relative to GAPDH mRNA expression in the presence or absence of SB-431542 $(20 \mu \mathrm{mol})$ and/ or the MEK1 inhibitor PD98059 $(10 \mu \mathrm{mol})$ and/or $100 \mathrm{ng} / \mathrm{mL}$ BMP6 for 18 hours. All values are expressed relative to the average of the untreated control (1 through 4) mRNA values.

Additional file 4: Top: FPCL on control (mixture 1 through 4) and Dupuytren's fibroblasts (mixture 1 through 4) treated with 12-Otetradecanoylphorbol-13-acetate (TPA) $(100 \mathrm{nmol})$ in the presence or absence of rec. BMP6 (100 ng/mL) for 72 hours. Middle:

Representative images of each condition are shown. Bottom: Western blot analysis of phosphorylated extracellular signal-regulated kinase 1/2 (P-ERK1/2) and $\alpha$-smooth muscle actin ( $\alpha$-SMA) on primary control (mixture 1 through 4) and Dupuytren's fibroblasts (mixture 1 through 4) treated with TPA (100 nmol) in the absence or presence of rec. BMP6 $(100 \mathrm{ng} / \mathrm{mL})$ for 18 hours are depicted in the lower panel. $\beta$-actin was included as a loading control.

Additional file 5: 3-(4,5-dimethylthiazol-2-yl)-5-(3carboxymethoxyphenyl)-2-(4-sulfophenyl)-2H-tetrazolium (MTS)based proliferation assay of pooled control fibroblasts treated for four days with SB-431542 (20 $\mu \mathrm{mol})$ and/or the mitogen-activated protein kinase kinase 1 (MEK1) inhibitor PD98059 (10 $\mu \mathrm{mol})$ where indicated. Absorbance at $490 \mathrm{~nm}$ was measured daily, and the proliferation rate is stated relative to untreated cells at day 0 .
\end{abstract}

\section{Abbreviations}

BSA: Bovine Serum Albumin; DMEM: Dulbecco's Modified Eagle's Medium; H \& E: Haematoxylin and Eosin Stain; PBS: Phosphate-Buffered Saline; PCR: Polymerase Chain Reaction.

\section{Acknowledgements}

We are grateful to K Iwata (OSI Pharmaceuticals), K Sampath (Creative BioMolecules) and Novartis for reagents. The authors acknowledge the Department of Plastic Surgery (Academisch Medisch Centrum (AMC), Amsterdam, The Netherlands) for providing the tissue material used in this project. We thank Jos Mulder (Department of Pathology, AMC) and Wicky Tigchelaar (Department of Cell Biology and Histology, AMC) for help with cell culture and $\alpha$-SMA immunocytohistochemistry and Giorgio Perino and Stephen Doty (Hospital for Special Surgery, New York, NY, USA) for help with TGF- $\beta 3$ and P-Smad2 immunohistochemistry. We appreciate the statistical support provided by Karen Ruschke (Freie Universität Berlin, Berlin Germany). This project was funded by the Dutch Organization for Scientific Research (NWO 918.66.606), the Netherlands Initiative for Regenerative Medicine, the 
Centre for Biomedical Genetics, the Marti-Keuning Eckhardt Stichting and the German Diabetes Society.

\section{Author details}

'Department of Molecular Cell Biology and Centre for Biomedical Genetics, Leiden University Medical Center, Einthovenweg 20, 2333 ZC Leiden, The Netherlands. ${ }^{2}$ Institute for Chemistry and Biochemistry, Freie Universität Berlin, Thielallee 63, D-14195 Berlin, Germany. ${ }^{3}$ Department of Orthopedic Surgery, Academic Medical Center, Meibergdreef 9, 1100 DD, Amsterdam, The Netherlands.

\section{Authors' contributions}

CK and PtD designed the experiments, analysed the data and wrote the manuscript. CK performed the experiments. PtD supervised the research. PK obtained the patient material and isolated primary fibroblasts. PK analysed the immunohistochemical experiments. All of the authors discussed the results and commented on the manuscript.

\section{Competing interests}

The authors declare that they have no competing interests.

Received: 12 March 2011 Accepted: 28 June 2011

Published: 28 June 2011

\section{References}

1. Shaw RB Jr, Chong AK, Zhang A, Hentz VR, Chang J: Dupuytren's disease: history, diagnosis, and treatment. Plast Reconstr Surg 2007, 120:44e-54e.

2. Rayan GM: Dupuytren disease: anatomy, pathology, presentation, and treatment. J Bone Joint Surg Am 2007, 89:189-198.

3. Hinz B, Phan SH, Thannickal VJ, Galli A, Bochaton-Piallat ML, Gabbiani G: The myofibroblast: one function, multiple origins. Am J Pathol 2007, 170:1807-1816

4. Tomasek JJ, Vaughan MB, Haaksma CJ: Cellular structure and biology of Dupuytren's disease. Hand Clin 1999, 15:21-34.

5. Gabbiani G, Majno G: Dupuytren's contracture: fibroblast contraction? Ultrastructural study. Am J Pathol 1972, 66:131-146.

6. Kloen P: New insights in the development of Dupuytren's contracture: a review. Br J Plast Surg 1999, 52:629-635.

7. Heldin $\mathrm{CH}$, Miyazono $\mathrm{K}$, ten Dijke P: TGF- $\beta$ signalling from cell membrane to nucleus through SMAD proteins. Nature 1997, 390:465-471.

8. Inman GJ, Nicolás FJ, Callahan JF, Harling JD, Gaster LM, Reith AD, Laping NJ, Hill CS: SB-431542 is a potent and specific inhibitor of transforming growth factor- $\beta$ superfamily type I activin receptor-like kinase (ALK) receptors ALK4, ALK5, and ALK7. Mol Pharmacol 2002, 62:65-74.

9. Derynck R, Zhang YE: Smad-dependent and Smad-independent pathways in TGF- $\beta$ family signalling. Nature 2003, 425:577-584

10. Moustakas A, Heldin CH: Non-Smad TGF- $\beta$ signals. J Cell Sci 2005, 118:3573-3584.

11. Hinz B: Formation and function of the myofibroblast during tissue repair. J Invest Dermatol 2007, 127:526-537.

12. Tomasek JJ, Gabbiani G, Hinz B, Chaponnier C, Brown RA: Myofibroblasts and mechano-regulation of connective tissue remodelling. Nat Rev Mol Cell Biol 2002, 3:349-363.

13. Vaughan MB, Howard EW, Tomasek JJ: Transforming growth factor- $\beta 1$ promotes the morphological and functional differentiation of the myofibroblast. Exp Cell Res 2000, 257:180-189.

14. Kloen $P$, Jennings $C L$, Gebhardt MC, Springfield DS, Mankin HJ: Transforming growth factor- $\beta$ : possible roles in Dupuytren's contracture. J Hand Surg Am 1995, 20:101-108.

15. Badalamente MA, Sampson SP, Hurst LC, Dowd A, Miyasaka K: The role of transforming growth factor $\beta$ in Dupuytren's disease. J Hand Surg Am 1996, 21:210-215.

16. Baird KS, Crossan JF, Ralston SH: Abnormal growth factor and cytokine expression in Dupuytren's contracture. J Clin Pathol 1993, 46:425-428.

17. Zamora RL, Heights R, Kraemer BA, Erlich HP, Groner JP: Presence of growth factors in palmar and plantar fibromatoses. J Hand Surg Am 1994, 19:435-441.

18. Berndt A, Kosmehl H, Mandel U, Gabler U, Luo X, Celeda D, Zardi L, Katenkamp D: TGF $\beta$ and bFGF synthesis and localization in Dupuytren's disease (nodular palmar fibromatosis) relative to cellular activity, myofibroblast phenotype and oncofetal variants of fibronectin. Histochem J 1995, 27:1014-1020.

19. Wong M, Mudera V: Feedback inhibition of high TGF- $\beta 1$ concentrations on myofibroblast induction and contraction by Dupuytren's fibroblasts. Hand Surg Br 2006, 31:473-483.

20. Bisson MA, Beckett KS, McGrouther DA, Grobbelaar AO, Mudera V: Transforming growth factor- $\beta 1$ stimulation enhances Dupuytren's fibroblast contraction in response to uniaxial mechanical load within a 3-dimensional collagen gel. J Hand Surg Am 2009, 34:1102-1110.

21. Tse R, Howard J, Wu Y, Gan BS: Enhanced Dupuytren's disease fibroblast populated collagen lattice contraction is independent of endogenous active TGF- $\beta 2$. BMC Musculoskelet Disord 2004, 5:41.

22. Bisson MA, McGrouther DA, Mudera V, Grobbelaar AO: The different characteristics of Dupuytren's disease fibroblasts derived from either nodule or cord: expression of a-smooth muscle actin and the response, to stimulation by TGF- $\beta 1$. J Hand Surg Br 2003, 28:351-356.

23. Bisson MA, Mudera V, McGrouther A, Grobbelaar AO: The contractile properties and responses to tensional loading of Dupuytren's diseasederived fibroblasts are altered: a cause of the contracture? Plast Reconstr Surg 2004, 113:611-621.

24. Gressner OA, Gressner AM: Connective tissue growth factor: a fibrogenic master switch in fibrotic liver diseases. Liver Int 2008, 28:1065-1079.

25. Leask A, Parapuram SK, Shi-Wen X, Abraham DJ: Connective tissue growth factor (CTGF, CCN2) gene regulation: a potent clinical bio-marker of fibroproliferative disease? J Cell Commun Signal 2009, 3:89-94.

26. Battegay EJ, Raines EW, Seifert RA, Bowen-Pope D, Ross R: TGF- $\beta$ induces bimodal proliferation of connective tissue cells via complex control of an autocrine PDGF loop. Cell 1990, 63:515-524.

27. Shin SS, Liu C, Chang EY, Carlson CS, Di Cesare PE: Expression of bone morphogenetic proteins by Dupuytren's fibroblasts. J Hand Surg Am 2004, 29:809-814.

28. Weiskirchen R, Meurer SK, Gressner OA, Herrmann J, Borkham-Kamphorst E, Gressner AM: BMP-7 as antagonist of organ fibrosis. Front Biosci 2009, 14:4992-5012.

29. Petersen $M$, Thorikay M, Deckers $M$, van Dinther M, Grygielko ET, Gellibert F, de Gouville AC, Huet S, ten Dijke $P$, Laping NJ: Oral administration of GW788388, an inhibitor of TGF- $\beta$ type I and II receptor kinases, decreases renal fibrosis. Kidney Int 2008, 73:705-715.

30. Grinell $\mathrm{F}, \mathrm{Ho} \mathrm{CH}$ : Transforming growth factor $\beta$ stimulates fibroblastcollagen matrix contraction by different mechanisms in mechanically loaded and unloaded matrices. Exp Cell Res 2002, 273:248-255.

31. Hinz B, Celetta G, Tomasek JJ, Gabbiani G, Chaponnier C: a-smooth muscle actin expression upregulates fibroblast contractile activity. Mol Biol Cell 2001, 12:2730-2741.

32. Rayan GM, Tomasek JJ: Generation of contractile force by cultured Dupuytren's disease and normal palmar fibroblasts. Tissue Cell 1994, 26:747-756.

33. Augoff K, Kula J, Gosk J, Rutowski R: Epidermal growth factor in Dupuytren's disease. Plast Reconstr Surg 2005, 115:128-133.

34. Baird KS, Crossan JF, Ralston SH: Abnormal growth factor and cytokine expression in Dupuytren's contracture. J Clin Pathol 1993, 46:425-428.

35. Alessi DR, Cuenda A, Cohen P, Dudley DT, Saltiel AR: PD 098059 is a specific inhibitor of the activation of mitogen-activated protein kinase kinase in vitro and in vivo. J Biol Chem 1995, 270:27489-27494.

36. Carroll M, Ohno-Jones S, Tamura S, Buchdunger E, Zimmermann J, Lydon NB, Gilliland DG, Druker BJ: CGP 57148, a tyrosine kinase inhibitor, inhibits the growth of cells expressing BCR-ABL, TEL-ABL, and TELPDGFR fusion proteins. Blood 1997, 90:4947-4952.

37. Solorzano CC, Baker CH, Tsan R, Traxler P, Cohen P, Buchdunger E, Killion J J Fidler IJ: Optimization for the blockade of epidermal growth factor receptor signaling for therapy of human pancreatic carcinoma. Clin Cancer Res 2001, 7:2563-2572.

38. Ozaki H, Seo MS, Ozaki K, Yamada H, Yamada E, Okamoto N, Hofmann F, Wood JM, Campochiaro PA: Blockade of vascular endothelial cell growth factor receptor signaling is sufficient to completely prevent retinal neovascularization. Am J Pathol 2000, 156:697-707.

39. Dandré F, Owens GK: Platelet-derived growth factor-BB and Ets-1 transcription factor negatively regulate transcription of multiple smooth muscle cell differentiation marker genes. Am J Physiol Heart Circ Physiol 2004, 286:H2042-2051. 
40. Masszi A, Speight P, Charbonney E, Lodyga M, Nakano H, Szászi K, Kapus A: Fate-determining mechanisms in epithelial-myofibroblast transition: major inhibitory role for Smad3. J Cell Biol 2010, 188:383-399.

41. Vindevoghel L, Lechleider RJ, Kon A, de Caestecker MP, Uitto J, Roberts AB, Mauviel A: SMAD3/4-dependent transcriptional activation of the human type VII collagen gene (COL7A1) promoter by transforming growth factor 3 . Proc Natl Acad Sci USA 1998, 95:14769-1474.

42. Deckers M, van Dinther M, Buijs J, Que I, Löwik C, van der Pluijm G, ten Dijke $P$ : The tumor suppressor Smad4 is required for transforming growth factor $\beta$-induced epithelial to mesenchymal transition and bone metastasis of breast cancer cells. Cancer Res 2006, 66:2202-2209.

43. Goumans MJ, Valdimarsdottir G, Itoh S, Lebrin F, Larsson J, Mummery C, Karlsson S, ten Dijke P: Activin receptor-like kinase (ALK) 1 is an antagonistic mediator of lateral TGF $\beta / A L K 5$ signaling. Mol Cell 2003, 12:817-828.

44. Daly AC, Randall RA, Hill CS: Transforming growth factor $\beta$-induced Smad1/5 phosphorylation in epithelial cells is mediated by novel receptor complexes and is essential for anchorage-independent growth. Mol Cell Biol 2008, 28:6889-6902.

45. Nguyen TQ, Chon H, van Nieuwenhoven FA, Braam B, Verhaar MC, Goldschmeding R: Myofibroblast progenitor cells are increased in number in patients with type 1 diabetes and express less bone morphogenetic protein 6: a novel clue to adverse tissue remodelling? Diabetologia 2006, 49:1039-1048.

46. Noble J, Heathcote JG, Cohen H: Diabetes mellitus in the aetiology of Dupuytren's disease. J Bone Joint Surg Br 1984, 66:322-325.

47. Perron JC, Dodd J: ActRIIA and BMPRII type II BMP receptor subunits selectively required for Smad4-independent BMP7-evoked chemotaxis. PLoS One 2009, 4:e8198.

48. Song K, Krause C, Shi S, Patterson M, Suto R, Grgurevic L, Vukicevic S, van Dinther M, Falb D, ten Dijke P, Alaoui-Ismaili MH: Identification of a key residue mediating bone morphogenetic protein (BMP)- 6 resistance to noggin inhibition allows for engineered BMPs with superior agonist activity. J Biol Chem 2010, 285:12169-12180.

49. Javelaud D, Mauviel A: Crosstalk mechanisms between the mitogenactivated protein kinase pathways and Smad signaling downstream of TGF- $\beta$ : implications for carcinogenesis. Oncogene 2005, 24:5742-5750.

50. Chen Y, Blom IE, Sa S, Goldschmeding R, Abraham DJ, Leask A: CTGF expression in mesangial cells: involvement of SMADs, MAP kinase, and PKC. Kidney Int 2002, 62:1149-1159.

51. Leask A, Holmes A, Black CM, Abraham DJ: Connective tissue growth factor gene regulation: requirements for its induction by transforming growth factor- $\beta 2$ in fibroblasts. J Biol Chem 2003, 278:13008-13015.

52. Guo B, Inoki K, Isono M, Mori $H$, Kanasaki K, Sugimoto T, Akiba S, Sato T, Yang B, Kikkawa R, Kashiwagi A, Haneda M, Koya D: MAPK/AP-1-dependent regulation of $\mathrm{PAl}-1$ gene expression by TGF- $\beta$ in rat mesangial cells. Kidney Int 2005, 68:972-984.

53. Stratton R, Rajkumar V, Ponticos M, Nichols B, Shiwen X, Black CM, Abraham DJ, Leask A: Prostacyclin derivatives prevent the fibrotic response to TGF- $\beta$ by inhibiting the Ras/MEK/ERK pathway. FASEB J 2002, 16:1949-1951.

54. Bhattacharyya S, Chen SJ, Wu M, Warner-Blankenship M, Ning H, Lakos G, Mori Y, Chang E, Nihijima C, Takehara K, Feghali-Bostwick C, Varga J: Smadindependent transforming growth factor- $\beta$ regulation of early growth response- 1 and sustained expression in fibrosis: implications for scleroderma. Am J Pathol 2008, 173:1085-1099.

55. Leask A: Potential therapeutic targets for cardiac fibrosis: TGF $\beta$, angiotensin, endothelin, CCN2, and PDGF, partners in fibroblast activation. Circ Res 2010, 106:1675-1680.

56. Trojanowska M: Role of PDGF in fibrotic diseases and systemic sclerosis. Rheumatology (Oxford) 2008, 47(Suppl 5):v2-v4.

57. Bonner JC: Regulation of PDGF and its receptors in fibrotic diseases. Cytokine Growth Factor Rev 2004, 15:255-273.

58. Levitzki A: PDGF receptor kinase inhibitors for the treatment of PDGF driven diseases. Cytokine Growth Factor Rev 2004, 15:229-235.

59. Distler JH, Distler O: Tyrosine kinase inhibitors for the treatment of fibrotic diseases such as systemic sclerosis: towards molecular targeted therapies. Ann Rheum Dis 2010, 69(Suppl 1):i48-i51. doi:10.1186/1755-1536-4-14

Cite this article as: Krause et al:: Elevated transforming growth factor $\beta$ and mitogen-activated protein kinase pathways mediate fibrotic traits of Dupuytren's disease fibroblasts. Fibrogenesis \& Tissue Repair 2011 4:14.

\section{Submit your next manuscript to BioMed Central and take full advantage of:}

- Convenient online submission

- Thorough peer review

- No space constraints or color figure charges

- Immediate publication on acceptance

- Inclusion in PubMed, CAS, Scopus and Google Scholar

- Research which is freely available for redistribution 